\title{
"A DAY OF MOST HEARTFELT SORROW": DEATH AND TEXAS IN WALT WHITMAN'S "SONG OF MYSELF"
}

\author{
Cliff Hudder
}

"I TELL NOT THE FALL OF AlAmo," begins what would eventually become Section 34 of Walt Whitman's "Song of Myself," yet despite this alert from the poet regarding what he will "tell not," the section was summarized in Gay Wilson Allen's seminal 1946 Walt Whitman Handbook as one of the poem's "interruptions to narrate some historical incidentsthe Alamo and an 'old fashioned frigate' fight." 'Richard Chase's 1955 work, Walt Whitman Reconsidered, likewise mentioned the "passages about the Alamo" featured in the poem. ${ }^{2}$ In fact, as more recent commentators have noted, the section recounts a different event from the 1836 Texas Revolution, the defeat and capture of Colonel James W. Fannin Jr.'s troops at the Battle of Coleto, and their massacre at nearby Goliad seven days later. Milton Hindus, pointing out Chase's error, is philosophical about such oversights; after all, the Goliad Massacre is "an obscure historical episode of the Texas fight for independence," he offers, and he asks, fairly enough: "Is it not characteristic of Whitman's poetical method, which always celebrates the leaves of grass in preference to the more showy flowers, to pick out the less well-known event rather than the better known one?"3

The event's obscurity, and even its occurrence in a geographical region physically distant from much of the settled Union, seem logical enough explanations for the poet's inclusion of the Goliad Massacre in "Song of Myself," a poem whose purpose was, as Peter Coviello puts it, "not merely to represent the nation to itself, but to facilitate nationality, to sponsor the sorts of far-flung bonds between citizens of which 'the nation' proper is made." ${ }^{\prime 4}$ But while it is true that the Goliad Massacre remains, as Hindus puts it, an "obscure historical incident"-outside of the Lone Star State at any rate-it was not so "far-flung" from public consciousness at the time of the first appearance of Leaves of Grass in 1855, and evidence indicates that Whitman himself was well aware of the mass slaying many years before composing this section of his poem. A closer examination of the poet's account of Goliad can help enrich our understanding of Whitman's relationship to his material, as well as enhance our understanding of the role that warfare plays in Whitman's 
art overall. One possible historical source for Whitman's account, a Mexican officer's letter, presents a voice that harmonizes well with that of the persona encountered in "Song of Myself," and offers an opportunity to examine that persona in light of Border Theory - the idea of the poet as boundary crosser, reconciler of dichotomies, and instrumental "go-between." Finally, an examination of changes in the series of revisions to the Goliad section in editions of Leaves of Grass subsequent to the 1855 version indicate how, after his personal experience of war in the 1860 s, Whitman critically re-evaluated the place of human violence in his poetic program.

Here is Whitman's 1855 version of the incident:

I tell not the fall of Alamo .... not one escaped to tell the fall of Alamo, The hundred and fifty are dumb yet at Alamo.

Hear now the tale of a jetblack sunrise,

Hear of the murder in cold blood of four hundred and twelve young men.

Retreating they had formed in a hollow square with their baggage for breastworks,

Nine hundred lives out of the surrounding enemy's nine times their number was the price they took in advance,

Their colonel was wounded and their ammunition gone,

They treated for an honorable capitulation, received writing and seal, gave up their arms, and marched back prisoners of war.

They were the glory of the race of rangers,

Matchless with a horse, a rifle, a song, a supper or a courtship,

Large, turbulent, brave, handsome, generous, proud and affectionate,

Bearded, sunburnt, dressed in the free costume of hunters,

Not a single one over thirty years of age.

The second Sunday morning they were brought out in squads and massacred .... it was beautiful early summer,

The work commenced about five o'clock and was over by eight.

None obeyed the command to kneel,

Some made a mad and helpless rush .... some stood stark and straight,

A few fell at once, shot in the temple or heart .... the living and dead lay together,

The maimed and mangled dug in the dirt .... the new-comers saw them there;

Some half-killed attempted to crawl away,

These were dispatched with bayonets or battered with the blunts of muskets;

A youth not seventeen years old seized his assassin till two more came to release him,

The three were all torn, and covered with the boy's blood.

At eleven o'clock began the burning of the bodies;

And that is the tale of the murder of the four hundred and twelve young men,

And that was a jetblack sunrise. (PP, 66-67) 
There are several superficial characteristics that make the Goliad Massacre well suited to Whitman's masterwork. The "four hundred and twelve young men" shot down in the incident stand in his version as representatives of those very types he describes in the 1855 Preface to Leaves of Grass as possessing the "genius of the United States": "Their manners speech dress friendships - the freshness and candor of their physiognomy - the picturesque looseness of their carriage," as well as "their aversion to anything indecorous or soft or mean" (PP, 5-6), are all found in the victims of Section 34:

They were the glory of the race of rangers,

Matchless with a horse, a rifle, a song, a supper or a courtship,

Large, turbulent, brave, handsome, generous, proud and affectionate,

Bearded, sunburnt, dressed in the free costume of hunters.

When commanded to kneel, the men- "not a single one over thirty years of age"-all refuse. A "youth not seventeen years old" turns on his assassins in what might be considered the climax of the section, though there are three of them and only one of him, emblematic of the Preface's characterization of "the common people" of America: "their deathless attachment to freedom," "the fierceness of their roused resentment," and "the air they have of persons who never knew how it felt to stand in the presence of superiors" $(P P, 6)$. "The instincts of the American people are all perfect," Whitman says in his 1856 letter to Ralph Waldo Emerson, "and tend to make heroes" (PP, 1353).

That the "heroes" of Goliad were acting at the periphery of the United States as it existed in 1855 might have likewise proven attractive to a poet who, as he states in the same letter to Emerson, wanted to begin "founding a literature" for a country separate from the "authors, publishers, importations, reprints, and so forth" of Europe (PP, 1351): "Walking freely out from the old traditions, as our politics has walked out, American poets and literats recognize nothing behind them superior to what is present with them" (PP, 1357). Here Whitman produces a note other "post-colonials" will sound after him, as when Ngũgĩ wa Thiong'o recalls "the excitement of reading the world from a centre other than Europe." Indeed, it is even tempting to see the inclusion of the incident as Whitman's attempt to reach outwards as far as he could geographically to add one more item to his pan-optic, multi-faceted catalogue of America, in this case another slant on human conflict in wartime: not like the honorific last words of the dying general who "gasps through the clot .... Mind not me .... mind ... . the entrenchments" $(P P, 66)$, which precedes the Goliad material at the end of Section 33, nor the victorious if bloody triumph of the Bon Homme Richard which follows in Section 35, but a description of war 
appropriate more to the slaughter of cattle or pigs than humankind: "The work commenced about five o'clock and was over by eight."

In asking why the incident should warrant an entire section of "Song of Myself," however, none of these purposes seems sufficient. For context, it is instructive to examine the poet's views on Texas, Mexico, and the Goliad Massacre itself before 1855. Emory Holloway in Whitman: An Interpretation in Narrative pointed out in 1926 how the poet-then journalist-had read in Blackwood's Edinburgh Magazine an account of Goliad one month before the Mexican War began in 1846, and that "years later he had no difficulty in retelling the experience in the first person as one of the incidents in his imaginative history fit to be recorded side by side with episodes in his personal life." ${ }^{6}$ Holloway's book, winner of the 1927 Pulitzer Prize in biography, contains no notes or documentation regarding these dramatic retellings, but Whitman was editor of the Brooklyn Daily Eagle when it ran extracts of the Blackwood's article as "Fanning's Men, or The Massacre at Goliad" on March 14, 1846. The article, composed for the most part of an account from one of the few survivors of the massacre, German immigrant to Texas Von H. Ehrenberg, contains several descriptions that parallel Whitman's version, including the refusal to kneel, although Ehrenberg admits that, since the command was given in Spanish, "few of us understood the order." "The blood of our lieutenant was on my clothes," he relates, "and around me lay my friends convulsed with their last agonies" - an image recalling the poem's encounter between the "youth not seventeen years old" who struggles with his attackers: "The three were all torn, and covered with the boy's blood."7

In addition to the Blackwood's article, Whitman's take on the massacre is evinced in editorials occasioned by the Mexican War and the annexation of Texas in the mid 1840s, penned while Whitman was editor of the Eagle. Goliad appears much on his mind in an article of May 11, 1846, where, in a piece titled "Shall We Fight It Out?," he emphasizes "the sickening story of those brutal wholesale murders, so useless for any purpose except gratifying the cowardly appetite of a nation of bravos, willing to shoot down men by the hundred in cold blood." A month later, an editorial entitled "Annexation" isn't about adding Texas to the Union, but rather a report on how "in several of the departments of Mexico . . . there is a wide popular disposition to come under the wings of our eagle," hence putting Whitman in league with those who did not consider the Rio Grande the southernmost reach of United States' Manifest Destiny (Fourn, 1:403). Jerome Loving in his biography Walt Whitman: Song of Himself (1999) reminds us that, even though by 1848 Whitman had lost his job at the Eagle, he had also very soon thereafter relocated himself as physically close to 
Texas as he would ever come, moving to "far-flung" New Orleans after a torturous fourteen-day steamboat journey. Loving sees Whitman as actively engaged in the matters concerning Texas during this time, New Orleans being a principal staging area for the return of troops after the successful close of the Mexican War. ${ }^{9}$ We will see that the earlier Texas Revolution, and the events of Goliad in particular, were quite prevalent in published justifications for conduct of that war and in discussions regarding the finalization of Texas statehood at that time.

Readers of the poem, however, will recognize that Section 34 bears little resemblance to the imperialistic and expeditionary bombast found in Whitman's editorializing of the 1840s. Loving assesses Whitman as evolving, by 1855, into a kind of "political dropout"-withdrawing from the conventions of politics much as he had from the conventions of rhyming poetry. "Through his book," writes Loving, "he absorbed the political poisons along with the vast diversity of democratic life, as America grappled with issues of geographic expansion, slavery, the Mexican War, and the dispute with Great Britain over the Oregon Territory." 10 Certainly there is no reason to believe that Goliad serves "Song of Myself" in the same capacity it served the editorial writer of 1846 in "Shall We Fight It Out?" "In war he is the most deadly force of the war," says Whitman of the "great poet" in his Preface to the first edition of Leaves of Grass, but he also notes, "if peace is the routine out of him speaks the spirit of peace, large, rich, thrifty" $(P P, 9)$. If warbe it honorable defeat, costly victory, or treacherous slaughter-is no longer used as nationalist rhetoric by the poet in 1855, what then is its role in his work? An examination of a particular source for the Goliad story that Whitman most likely encountered offers an intriguing line of inquiry.

In what is probably the most thorough examination of the sources of Whitman's Goliad description, Whitman's Song of Myself 34 and Its Background (1969), D. M. McKeithan finds several parallels between the poem's account and a much publicized letter written by a supposed witness to the massacre, a Mexican officer communicating home to his wife and deploring the event. That there were ample opportunities for Whitman to encounter the letter, especially during a period he was interested in the conduct of the Mexican War, is well established, although its authenticity as a letter from an actual Mexican officer is much less certain. McKeithan's monograph traces the letter not to any identifiable Mexican officer, but to the Frankfort, Kentucky, Commonwealth of June 16, 1836, and there credited to the New Orleans Bee. ${ }^{11}$ Very soon thereafter, the letter, slightly altered in wording from the version found in the Commonwealth, appears in History of South America and Mexico and $A$ Geographical and Historical View of Texas (1837) by John M. Niles 
and L. T. Pease, Pease's contribution being the Texas material. ${ }^{12}$ The difference in wording suggests the possibility of translation from an earlier, Spanish, source. Later the letter appeared several times during the run-up to the Mexican War, prominently featured in a congressional address by George A. Caldwell of Kentucky in January of 1845 and a Senate speech by New York's Daniel Dickinson in February of the same year as both politicians drummed up support for the annexation of Texas. ${ }^{13}$ Both times the letter was attributed to "Pease's Texas History." In 1847, Samuel Gregory's History of Mexico also reprinted the letter as it appeared in Pease's volume, as did Nathan Covington Brooks two years later in A Complete History of the Mexican War, Its Causes, Conduct, and Consequences (1849). ${ }^{14}$

The most striking evidence for the letter as a source for the poem, however, is not chronological, or historical, but internal. Here is the version as it appears in Pease, in its most frequently repeated form, and from its most frequently cited source:

In dismissing the subject [of Goliad], however, we will introduce one other witness to speak for us, who also bore a part in the tragic scene. ... He was an instrument of the assassin, (and as it would appear from his language, an unwilling instrument,) in consummating the foul deed. We extract the following from a letter written by a Mexican officer after the massacre: -

"This day, Palm Sunday, March 27, has been to me a day of most heartfelt sorrow. At six in the morning, the execution of four hundred and twelve American prisoners was commenced, and continued till eight, when the last of the number was shot. At eleven commenced the operation of burning their bodies. But what an awful scene did the field present, when the prisoners were executed, and fell dead in heaps! and what spectator could view it without horror! They were all young, the oldest not more than thirty, and of fine florid complexions. When the unfortunate youths were brought to the place of death, their lamentations and the appeals which they uttered to heaven, in their own language, with extended arms, kneeling or prostrate on the earth, were such as might have caused the very stones to cry out in compassion." (339) [italics added]

McKeithan points to that very specific number of "four hundred and twelve" as the strongest evidence for the letter as a Whitman source. Actual historical estimates numbering the dead at Goliad vary widely, but McKeithan could find none beyond this letter that mentioned the exact figure that appears in Section 34. In addition, he finds that, while several accounts report the burning of the bodies, the fact that the exact time of its commencement, eleven o'clock, is found in both letter and poem argues for the letter as a Whitman source (42). As is obvious from the emphasized passages above, other features of the letter are also closely echoed in the poem- "Not a single one over thirty years of age," for example - although what Whitman called the "work" of killing commenced at six o'clock in the officer's version, rather than five o'clock 
in Whitman's telling. McKeithan concludes that this background information helps us read Section 34 with greater appreciation of the poet's "superb economy of words, vividness of detail, and restraint of emotion" (42). I would argue that the letter tells us even more.

It is true that Whitman's restraint is evident. Failing to mention that the massacre occurred on Palm Sunday, for example, must be considered purposeful, and is a fact that Nathan Covington Brooks's $A$ Complete History of the Mexican War (1849) emphasizes with enflamed language while discussing the very same Mexican officer's letter, bemoaning: "this act of savage ferocity . . . committed upon the day of the Prince of Peace . . . the smoke of the burning bodies desecrating and polluting the still Sabbath air" (45). All of this is reduced in "Song of Myself" to "The second Sunday morning." More interesting than anything borrowed or subtracted from the alleged source, however, is the figure of its author, the Mexican officer as described in nearly all published accounts as a "witness," present in "consummating the foul deed," yet also an "unwilling instrument" in that consummation.

While the account of Goliad in "Song of Myself" has been largely ignored by scholars, various critical attempts to discern the structure of the poem allow us to speculate about the placement of Section 34 within the architecture of the poem as a whole, and such placement is instructive when considering how the narrative of the Mexican officer might have resonated with Whitman. Herbert J. Levine's 1987 article, "Union and Disunion in 'Song of Myself"" locates the Goliad material in a "third phase of the poem's plot, Reunion, [where] Whitman embarks on a journey through space and time, taking in American places, people and the wars that founded and expanded the country, demonstrating, as in other catalogue sequences, the myriad connections possible and necessary in a unified democratic land." ${ }^{15}$ Malcom Cowley sees Sections 30-38 as concerning "the power of identification": "[Whitman] can identify himself with every object and with every person living or dead, heroic or criminal. Thus he is massacred with the Texans at Goliad." 16 Such a formulation of a connecting, universally identifying figure is found in a much discussed notebook passage drafted by Whitman just before composing "Song of Myself":

I go with the slaves of the earth equally with the masters

And I will stand between the masters and the slaves,

Entering into both so that both shall understand me alike. ${ }^{17}$

Ed Folsom sees this notebook entry as the point where Whitman "probes for a voice that reconciles the dichotomies" (50). Karen Sánchez-Eppler finds evidence of Whitman's own conception of the poet as a "site of mediation" going back to these passages; and in the "thoroughly demo- 
cratic 'I"' that appears throughout Leaves of Grass, David S. Reynolds finds "vision in which all barriers ... were challenged in unprecedented ways." Loving, speaking of the way that the poet "exhausted his journalistic opportunities" in the 1840's, labels the Whitman of 1855 "the 'witness' who waits." 18

While rhetorically the Mexican officer's letter might seem especially damning-something on the order of "even the savage enemy views this scene with horror!"-it may also have presented in its narrative perspective an attractive model for the poet, attempting as he was to be a similar, albeit willing, instrument of "go-between"- a witness. While it can't be said for certain that there ever was a Mexican officer who penned this letter, the persona - that of an outsider in Texas, yet one obviously sympathetic to those who should by all rights be his enemies-recalls Salmon Rushdie's claim that it may well be the sense of being "elsewhere" that allows the immigrant "to speak properly and concretely on a subject of universal significance and appeal."19

Thinking along those lines, I do not believe it is only the nearness of Section 34's physical setting to the southern border of the United States that brings to mind other kinds of "line crossers" who, like the Mexican officer, present themselves as figures who challenge barriers and categories in a way appropriate to Whitman's project, especially in its 1855 version. The officer (who, as the letter is framed, is also attempting to communicate his experience across the gender line by writing to his wife) evokes Gloria Anzaldúa's la mestiza who transcends border zones and other categories: "those who cross over, pass over, or go through the confines of the 'normal."' 20 Sara Lee Spurgeon sees figures like la mestiza and Native American trickster characters such as Coyote as neither transcending divisions (assassin/victim, comrade/enemy, Texan/ Mexican), nor dissolving categories, but "embracing them and building affinity across difference"-or, as Whitman's notebook entry puts it: "Entering into both so that both will understand me alike." 21 Paralleling the poetic persona encountered in "Song of Myself," the role the officer takes in his letter might well have proven very attractive to the poet of reunion and identification.

It would be helpful in support of this view to find evidence in Section 34 that Whitman is attempting to build "affinity across difference" rather than simply offering a more sober, restrained account of a heartless massacre in a far-flung part of the nation. Just as "Song of Myself" removes Palm Sunday from its rendering of the event, it includes something that is found nowhere in the officer's letter, and that McKeithan could find in no other source-that struggle of the sixteen-year-old who "seized his assassin," then fought until two more Mexican soldiers arrive to grapple with him. Here, at what I have called 
the climax of Section 34, we encounter the aforementioned "three . . all torn, and covered with the boy's blood." While I would not argue that such splatter parallels the "sous[ing] with spray" that figuratively unifies the poem's "twenty-ninth bather" with the objects of her desire, nor go so far as to argue the moment as a "euphemistic moistening exemplify[ing] the scattering of the spermatic persona's fertilizing seed," after the fashion of Harold Aspiz, the poet has used blood in other parts of Leaves of Grass for similarly unifying and barrier-challenging purposes. "Whatever goes to the tilth of me it shall be you," Whitman says, seeking out objects of union to worship earlier in the poem, including: "You my rich blood, your milky stream pale strippings of my life" $(P P, 51)$. Even more to the point is that liquid which makes the "curious creature" that is a slave in "I Sing the Body Electric" not so curious after all, but brother under the flesh to all readers: "Within there runs his blood .... the same old blood .. the same red running blood" (PP, 123). Returning to that other likely source of Whitman's familiarity with the Goliad Massacre, the Blackwood's article as reprinted in the Brooklyn Daily Eagle, it is notable that Ehrenberg's description of the "blood of our lieutenant" that he finds on his own clothes is made in Section 34 to splash across the comrade/enemy divide: the image found in the German immigrant's account perhaps altered by Whitman to deliver something more in the spirit of the Mexican officer's boundary-crossing letter. ${ }^{23}$

In the blood-anointed image of the three Mexican soldiers and the "youth not seventeen," we find an act of deception and treachery ending in a kind of blood brotherhood. War is treated here as a zone of category scrambling, or-in keeping with the border theme-something akin to what Avtar Brah calls "diaspora space": "an intersection of borders where all subjects and identities become juxtaposed, contested, proclaimed, or disavowed; where the permitted and prohibited perpetually interrogate, and where the accepted and trangressive imperceptibly mingle." ${ }^{24}$ What should be seen as conflict, then, begins to look more like what is mentioned in introductions to the officer's letter: a consummation. Indeed, we learn that we will "Hear the tale of a jetblack sunrise" as the section begins: the phrase is a melding of blackness and light, qualities that should usually be held in juxtaposition but are instead combined as a meeting and mixing of opposites in a way that transgresses the normal manner in which dawns actually occur. Indeed, categories arise in Section 34 only to waver and shift: "Prisoners of war," a protected class for all civilized nations, are treated in the poem like condemned criminals in an act of extermination that is described by a term more appropriate to everyday breadwinning: "work." War, in "Song of Myself," becomes an opportunity for Whit- 
man to shatter divisions, subjects, and identities in an act that might well be considered as unifying as it is destructive. "And that was a jetblack sunrise," the section concludes, presenting the same categoryscrambling paradox of illumination and darkness with which it began. The Whitman of this section is much like the Mexican officer himself, who in his letter identifies with the "lamentations and ... appeals" of the dying Texans-his own enemies and criminals in the eyes of the Mexican authorities - and further identifies even with inanimate nature - the sounds of those victims being, as he says, "such as might have caused the very stones to cry out in compassion."

Considering the Goliad section in this way allows for a fresh approach when we examine alterations that occurred in the poet's long process of reformulating Leaves of Grass through many revisions over several decades. Indeed, by the third (1860) edition, one of the category-blending aspects of the 1855 version, the paradoxical "jetblack sunrise," has disappeared entirely, perhaps by then viewed by Whitman as poetically rich but not truly accurate to any sort of dawn that would occur "in beautiful early summer" on a day of slaughter. Importantly, Whitman also alters "the second Sunday morning" as the day of the tragedy, re-labeling it in the parlance of Quakers: "The second First-day morning." 25 As the editors of the 1965 version of the Comprehensive Reader's Edition of Leaves of Grass point out, that group's "pacifist inclination unites with the ideas of Sunday in strong contrast with the massacre," bringing the effect much closer to what could have been achieved had Whitman accurately reported the event as occurring-as it did-on Palm Sunday in the first place. ${ }^{26}$ Whitman, by 1860 , would seem less willing to take liberties with accurate representation of the Goliad Massacre-less willing, that is, to treat the slaughter as a symbolic abstraction.

By the time of the 1867 edition-what Gay Wilson Allen calls "The Workshop Edition," filled with "revisions [that] indicate great critical activity"-changes are wrought that indicate the poet can indeed no longer accept an event like the Goliad Massacre, distant in time and space though it may be, as a mere zone of boundary challenge. ${ }^{27}$ The section's vantage point is subtly re-framed. Cowley finds the whole poem altered by 1867 , and calls special attention to a phrase Whitman inserts as a kind of introduction to the Goliad section: "Now I tell what I knew in Texas in my early youth"-not present at all until this edition. ${ }^{28}$ Cowley accuses the poet of "falsifying his own biography" in a manner that affects "the poet-hero's ability to identify himself with all creatures, living or dead," no longer unifying himself with the slain, and thus, for Cowley, causing the section itself to lose its reason for being part of the poem: "The good gray poet must have been abashed 
by many gestures of his earlier myself" (xxxv).

Perhaps, though, the explanation is much simpler. During the Civil War years, the poet had not been serving as an interstitial, "inbetween" figure, but as a hands-on participant in harrowing scenes of hospital life in the American Civil War. The changes occurring in Section 34-itself a grim scene of bloodshed - were not wrought merely by "critical activity," but also by a critical re-evaluation of the way the poet felt human violence could be used in his own aesthetic program. The new introductory phrase changes the barrier-crossing poet persona into someone simply recounting something he "knew" in the past-a distancing that places him outside the events of Goliad in comparison with the 1855, unified-identity point of view.

Indeed, that Whitman's attitude towards the Goliad section was evolving during the war years is further evidenced by the so called "Blue Book," a copy of the 1860 edition of Leaves of Grass in which the poet made marginal notes and plans for his next version of the work, both before and during his Washington sojourn. The facsimile edited by Arthur Golden shows the poet working through an early version of the "Now I tell what I knew in Texas in my early youth" passage, the line appearing as a marginal pencil addition that started out as "Hear now the deed at Goliad, in war." ${ }^{29}$ Whitman hence at some point considered that new versions of his poem could actually name the event that was "not the fall of the Alamo." The "Blue Book" also contains markings in the margins of the two-page-long Goliad section indicating that the entire episode should be eliminated-“out altogether"-from future editions. As Golden puts it (again defaulting to the most memorable massacre of the Texas revolution as a convenient if misleading label): "Apparently he felt at this point that the encounter between the BonHomme Richard and Serapis was enough. He later changed his mind, as he was to do with a number of Blue Book revisions, and retained the 'Alamo' section in the 1867 edition" ( $W W B B, 2$ :xli).

Such doubts about the section, however, and its reframing and distancing, indicate that the poet of the Washington D.C. hospitals was no longer using his imagination as his chief source when it came to the "maimed and mangled" victims encountered in Section 34. As he recorded in "The Dresser" (later "The Wound-Dresser"), Whitman by 1867 had seen "the perforated shoulder, the foot with the bulletwound," as well as the "gnawing and putrid gangrene, so sickening, so offensive" $(P P, 445)$. In his prose account of those years, Memoranda During the War (1876), rather than the nameless "youth not seventeen years old" who refuses to yield to his executioners, readers learn of "Charles Miller, bed No. 19, Company D, Fifty-third Pennsylvania . . . only sixteen years of age, very bright, courageous boy, left leg amputated below the 
knee," a specific, flesh-and-blood young man. This-Whitman's new, laborious, "in person" attempt to, as Coviello puts it, "make nation-ness happen"-comes from a persona who also speaks from the experience of war, from a position privileged enough to still see categories, but understanding his restricted ability to attain affinity across each and every one of them. This is the attitude with which he approached the 1867 revision of "Song of Myself." 30

This hardening of the boundaries is reflected in Whitman's revised vision of the nation itself as evidenced in Memoranda During the War, especially its closing section, "Future History of the United States, growing out of the War-(My Speculations.)," where the poet asks:

And, (as gold and silver are cast into small coin,) are not, for their elucidation, entirely new classes of men, uncommitted to the past, fusing The Whole Country, adjusted to its conditions, present and to come, imperatively required, Seaboard and Interior, North and South ? and must not such classes begin to arise, and be emblematic of our New Politics and our real Nationality? (132)

For Whitman, after the war, the fusing of our "real Nationality" requires not a crossing or mixing as such "fusings" usually do, but rather new "classes of men"-categories wherein the nation is subdivided, even "cast" just as solid coin denominations are separated out from the amalgam of metals from which they are formed. Interesting in light of his 1846 editorializing about bringing Latin American nations "under the wings of our eagle," "The Whole Country" seems now bounded between "Seaboard and Interior, North and South"-something also implied earlier in Memoranda when the poet complains about attitudes of foreign governments towards the United States "with the single exception of Mexico-Mexico, the only one to whom we have ever really done wrong, and now the only one who prays for us and for our triumph, with genuine prayer" (117). Contritely, after the Civil War, Whitman secures the border, making the nation's neighbor to the south exempt from continental Manifest Destiny after all.

Bearing as it does on Whitman's evolving vision of the poet's relationship to his material, his methods of revision, the representative types making up the "genius" of his nation, and the place of war in his oeuvre, Section 34 has been unjustly overlooked by scholars who examine the background and structure of "Song of Myself." If it is true that Whitman became uncomfortable with his own presentation of warfare after witnessing its brutality in a more personal manner, Section $34-$ as it makes its way through the various revised editions-is an instructive passage for examination. In fact, Whitman's discomfort over Goliad is not surprising. The "real" events of this incident continue to challenge categories up to the present time. Indeed, the Goliad Massacre 
has never been, to quote Milton Hindus again, "an obscure historical event" in history-drenched Texas, where every young person must learn about Fannin and his men to successfully move beyond the seventh grade. What is learned, however, has been under constant revision. The heroic colonel James Fannin-whose surname now graces schools, public buildings, and thoroughfares throughout Texas-is well understood these days to have made his fortune from the illegal African slave trade. Historian Paul D. Lack points out how one of Fannin's stated reasons for seeking Texan independence from Mexico was to prevent the prostitution of "the fair daughters of chaste white women" to a darker skinned race. ${ }^{31}$ Journalist Cecilia Balli reported in 2001 on a rising, rancorous debate among long-time residents of Goliad, Texas, about whether or not the term "massacre" even applies to the events of that Palm Sunday in 1836, with some Latino Texans preferring "execution" as a more accurate term. In our era of "enemy combatants," the difference is subtle but important: although many of his officers disagreed, Mexican General Santa Anna saw those killed at Goliad as pirates rather than soldiers and hence not technically "prisoners of war" at all..$^{32}$ It is fitting that the category-challenging events of Goliad attracted the attention of America's poet of unity, identity, and "allness," and it is intriguing to consider that it could have been a report from a Mexican witness to this "day of most heartfelt sorrow" that brought its occurrences so powerfully to Whitman's mind as he sought a new American voice with which to chant his masterwork, whether that witness actually existed or not.

Texas AEM University

\section{NOTES}

1 Walt Whitman: Poetry and Prose, ed. Justin Kaplan (New York: Library of America, 1996), 66. Hereafter, PP. Gay Wilson Allen, Walt Whitman Handbook (Chicago: Packard and Company, 1946), 119.

2 Richard V. Chase, Walt Whitman Reconsidered (New York: William Sloane Associates, 1955), 85.

3 Milton Hindus, "The Goliad Massacre in 'Song of Myself," Walt Whitman Review 7 (December 1961), 77-78.

4 Walt Whitman, Memoranda During the War, ed. Peter Coviello (Oxford: Oxford University Press, 2004), xxx.

5 Ngũgĩ wa Thiong'o, Moving the Centre: The Struggle for Cultural Freedoms (London: J. Currey, 1993), 4. 
6 Emory Holloway, Whitman: An Interpretation in Narrative (New York: Alfred A. Knopf, 1926), 30-31.

7 "Fanning's Men; orThe Massacre at Goliad," Brooklyn Daily Eagle (March 14, 1846), 2. Available on the Brooklyn Daily Eagle Online Archive (eagle.brooklynpubliclibrary.org).

8 Walt Whitman, The fournalism, ed. Herbert Bergman, Douglas Noverr, and Edward J. Recchia (New York: Peter Lang, 1998), 1:359. Hereafter, Fourn. The answer to the article's title, by the way, appears to be: "Yes: Mexico must be thoroughly chastised! .... we are sure the people here, ten to one, are for prompt and effectual hostilities" (1:358-359).

9 Jerome Loving, WaltWhitman:The Song of Himself (Berkeley: University of California Press, 1999), 116.

10 Jerome Loving, "The Political Roots of Leaves of Grass," in David S. Reynolds, ed., A Historical Guide to Walt Whitman (Oxford: Oxford University Press, 2000), 117.

11 D. M. McKeithan, Whitman's Song of Myself 34 and Its Background (Uppsala: Lundequistska Bokhandeln, 1969), 34.

12 John M. Niles and L. T. Pease, History of South America and Mexico; Comprising Their Discovery, Geography, Politics, Commerce and Revolutions to Which Is Annexed A Geographical and Historical View of Texas with a Detailed Account of the Texan Revolution and War (Hartford: H. Huntington, 1837), 339.

13 George A. Caldwell, "Annexation of Texas," Appendix to the Congressional Globe (January 21, 1845), 148; Daniel S. Dickinson, Speeches, Correspondence, Etc., of the Late Daniel S. Dickinson of New York (New York: G.P. Putnam and Son, 1867), 1:136.

14 Nathan Covington Brooks, A Complete History of the Mexican War, Its Causes, Conduct, and Consequences (Philadelphia: Grigg, 1849), 45-46; Samuel Gregory, Gregory's History of Mexico (Boston: F. Gleason, 1847), 55.

15 Herbert J. Levine, "Union and Disunion in 'Song of Myself," American Literature 59 (December 1987), 586.

16 Malcom Cowley, "Editor's Introduction," Leaves of Grass: The First 1855 Edition (New York: Penguin, 1986), xix.

17 Quoted in Ed Folsom, "Lucifer and Ethiopia: Whitman, Race, and Poetics before the Civil War and After," Reynolds, ed., Historical Guide, 50.

18 Karen Sánchez-Eppler, Touching Liberty: Abolition, Feminism, and the Politics of the Body (Berkeley: University of California Press, 1993), 54; David S. Reynolds, "Introduction," Historical Guide, 10; Loving, "Political Roots," 115.

19 Salman Rushdie, Imaginary Homelands: Essays and Criticism 1981-1991 (London: Granta Books, 1991), 12.

20 Gloria Anzaldúa, Borderlands/La Frontera: The New Mestiza (San Francisco: Aunt Lute, 1987), 3.

21 Sara Lee Spurgeon, "The Cyborg Coyote: Generating Theory in the Borderlands," Southwestern American Literature (Spring 2009), 17.

22 Harold Aspiz, "Walt Whitman: The Spermatic Imagination," American Literature 56 (October 1984), 383. 
23 That Whitman reports how "None obeyed the command to kneel" at Goliad, yet neglects to mention as Ehrenberg does how few among them understood Spanish, could be another example of altering the Blackwood's account in a way that increases "affinity across difference." While Whitman's version serves to increase the defiance of the Anglo figures in the poem, it also erases a language barrier across the Mexican/Texan divide.

24 Avtar Brah, Cartographies of Diaspora: Contesting Identities (London: Routledge, 1996), 208.

25 Walt Whitman, Leaves of Grass (Boston: Thayer \& Eldridge, 1860), 76. Available on the Walt Whitman Archive (www.whitmanarchive.org).

26 Walt Whitman, Leaves of Grass: Comprehensive Reader's Edition, ed. Sculley Bradley and Harold W. Blodgett (New York: New York University Press, 1965), 68n.

27 Gay Wilson Allen, The NewWalt Whitman Handbook (NewYork: New York University Press, 1975), 118.

28 Walt Whitman, Leaves of Grass (NewYork: 1867), 70. Available on the WaltWhitman Archive (www.whitmanarchive.org).

29 Walt Whitman, Walt Whitman's Blue Book, The 1860-61 Leaves of Grass Containing His Manuscript Additions and Revisions, ed. Arthur Golden (New York: New York Public Library, 1968), 1:76. Hereafter, WWBB.

30 Walt Whitman, Memoranda During the War, ed. Peter Coviello (Oxford: Oxford University Press, 2004), 12, xxx.

31 Paul D. Lack, "Slavery and the Texas Revolution," Southwestern Historical Quarterly (1985), 188. Emphasis in the original.

32 Cecilia Balli, “The Second Battle of Goliad,” Texas Monthly (May 2001), 142-143. 